\title{
Transnational Surrogacy in the Light of the Case-law of the European Court of Human Rights
}

\author{
Christian Kalin* \\ University of Passau \\ 41 Innstrasse, Passau, 94032, Germany
}

Received 24.04.2017, received in revised form 14.06.2017, accepted 15.06.2017

Surrogacy is a particularly sensitive issue. Therefore, the regulations of surrogacy by different European legal systems diverge significantly. According to the European Court of Human Rights it is, in principle, at the discretion of each signatory of the European Convention on Human Rights to allow or prohibit surrogacy. The decision of the Court's Second Section in the proceeding Paradiso and Campanelli, however, requires that signatories that generally reject surrogacy establish a legal parent-child-relationship between children born abroad due to surrogacy arrangements and their intended parents.

Keywords: Surrogacy, Descent, European Convention on Human Rights, Family life, European Court of Human Rights, Public policy.

DOI: 10.17516/1997-1370-0097.

Research area: law.

\section{I}

Determining the descent of a child is one of the most important tasks that every legal system is confronted with. In the past, the possible answers to the question of legal parenthood were very limited. In one way or another, the law was guided by the biological conditions of conception, pregnancy and birth. The legal mother was the woman who gave birth to the child, the legal father was the man who fathered the child. First and foremost, biological parentage - with regard to the father at least a presumed one - also led to legal parenthood.

In recent decades, however, advances in modern reproductive medicine have multiplied the number of possible responses to the question of legal parentage, thus leading to the need to regulate what has seemed self-evident so far. It is not surprising that the solutions that were found by different legal systems for such a delicate issue as human reproduction diverge not only globally, but also within Europe. An international consensus on this topic seems hardly conceivable.

\section{II}

These differences can be illustrated by the different approaches of the German and the Russian law towards surrogacy. The term surrogacy denotes circumstances in which a

(C) Siberian Federal University. All rights reserved

* Corresponding author E-mail address: christian.kalin@uni-passau.de 
woman - the surrogate mother - is subjected to an artificial fertilisation at the request of other persons - the intended parents - in order to hand over the child after its birth to the intended parents, who intend to raise it as their own.

1

Under German law this artificial fertilisation as well as the mediation of a surrogate mother is a criminal offense. ${ }^{1}$ In this way surrogacy and the legal and ethical conflicts, that accompany it, are supposed to be avoided from the outset. According to German law, therefore, the legal mother is always the woman who gave birth to the child. ${ }^{2}$

Similarly, surrogacy is - in principle - also rejected, for example, in France or Italy.

$$
2
$$

Russian law, on the other hand, follows a liberal approach towards surrogacy. Based on a contract between the surrogate mother and the intended parents, an artificial fertilisation of the surrogate mother may be carried out and the intended parents may be registered as the child's parents after the birth, thus obtaining legal parenthood. ${ }^{3}$ After this registration, legal parenthood of the intended parents can be challenged neither by them nor by the surrogate mother. ${ }^{4}$

To attain legal parenthood, however, the surrogate mother has to consent after the birth of the child. ${ }^{5}$ Thus, despite the agreement with the intended parents the surrogate mother always has the possibility to retain legal parenthood over the child. ${ }^{6}$

Surrogacy is allowed in several other countries as well. The mechanisms that are used to implement surrogacy, however, diverge considerably? Californian law, for example, provides for the participation of a state court, that acknowledges legal parenthood of the intended parents. ${ }^{8}$
3

The following circumstances are especially prone to cause conflicts: the intended parents, whose home country rejects surrogacy, use the services of a surrogate mother in a country which allows surrogacy. After the child's birth, the intended parents as well as the newborn child return to their home country; this results in a situation that, from this state's point of view, should have been averted from the outset by preventive prohibitions.

Typically, the intended parents also wish to be recognized by their home country as the legal parents of the child and to be registered accordingly. However, this is regularly denied by the authorities of their home country because it is contrary to the national prohibition of surrogacy to recognize a legal parenthood that was obtained abroad by means of surrogacy.

\section{III}

In judicial procedures concerning the legal parentage of the child, that may easily arise in these situations between the intended parents and their home country, the European Court of Human Rights (ECtHR) has had the opportunity to evaluate surrogacy in the light of the European Convention on Human Rights on various occasions. All proceedings concerned the question, whether a state that rejects and prohibits surrogacy may nonetheless be required to recognize legal implications attributed to surrogacy by a foreign law, that in this respect follows a more liberal approach. As the decisive factor for the evaluation of surrogacy the Court identifies the interests of the child. The answers, however, that are found on this basis are by no means free from ambiguity.

\section{1}

The first two judgements in the proceedings of Mennesson and Labassee, that were delivered 
by the Court in June 2014, dealt with surrogacy under US law. ${ }^{9}$ American courts awarded two married French couples the legal parenthood of children who had been born by American surrogate mothers, using donated ova and sperms of the intended fathers. Therefore, the children were not genetically related to the intended mothers, but at least to the intended fathers. American birth certificates identifying the intended parents as the children's legal parents were issued and the intended parents requested a corresponding registration in the French register of births. French authorities and courts rejected the intended parents' request because the recognition of the American court decision would mean to give effect to a surrogacy agreement that, from a French legal perspective, was void and against public policy because it infringed on fundamental principles of French law.

The European Court of Human Rights based its considerations on Article 8 of the Convention protecting private and family life. It first stated that due to the absence of a consensus between the signatories and the delicate ethical issues concerning surrogacy it was, in principle, at the discretion of each state to allow or prohibit surrogacy. ${ }^{10}$ However, when applying the public policy exception to the results of a foreign surrogacy, the signatories have to ensure a fair balance of interests with regard to the private and the family life of the parties involved. ${ }^{11}$

Article 8 of the Convention protects, on the one hand, factual family ties. ${ }^{12}$ Whether a signatory is willing to legally recognize the relationship between the intended parents and the child is not of importance to the protective scope of Article 8 of the Convention. It is sufficient that the intended parents and the child live together mutually caring for each other as families usually do. Private life, on the other hand, which is likewise protected by Article 8 of the Convention, includes the identity of a person. ${ }^{13}$ A person's identity is essentially determined by the descent of his or her parents. According to the case law of the Court, Article 8 of the Convention therefore requires the signatories to provide for a reliable legal descent for every person.

In the cases of Mennesson and Labassee, the Court concluded that the intended parents' right to respect for their family life had not been violated. Despite the fact that the French authorities had refused to recognize the American court decisions, the intended parents were not prohibited to live with the child in a factual family. ${ }^{14}$

However, the children's right to respect for their private life had been violated. It is contrary to the children's interests to deny them a legal parentage that was established abroad under a foreign law. ${ }^{15}$ The Court attached particular weight to the fact that there was a genetic link between the children and their respective intended fathers. ${ }^{16}$ It is not permissible to infringe the relationship between the child and its intended parents by denying a legal parentage, at least if this relationship is consolidated by a genetic link. The preventive prohibition of surrogacy must not lead to a restriction of the children's rights who are - despite the prohibition - born due to a surrogacy arrangement.

\section{2}

Despite its fundamental rejection in German law, surrogacy has, to a certain extent, become part of the German legal system in the wake of these judgements. The end of 2014, the Federal Court of Justice (BGH) ruled that the recognition of a foreign court decision, which provides for a legal descent of the child from the intended parents, does not violate German public policy. ${ }^{17}$ This applies at least, if the surrogate mother has voluntarily agreed to give up the child after its birth and if at least one of the intended parents is genetically related to it. ${ }^{18}$ 
3

However, there are still a lot of pending questions concerning transnational surrogacy which have not been answered by a further judgement of the European Court of Human Rights in the case Paradiso and Campanelli ${ }^{19}$, that was delivered in the year 2015.

In this case, the intended parents from Italy used the services of a surrogate mother in Russia and obtained a Russian birth certificate which identified them as the child's legal parents. They demanded a corresponding registration in the Italian register of births and the acknowledgement of their legal parenthood of the child by the Italian state.

As it turned out, the child was genetically not related to the intended parents. For the artificial fertilisation in Russia instead of the sperms of the intended father those of an unknown donor had - probably inadvertently - been used. ${ }^{20}$ Thereupon, Italian authorities and courts refused to acknowledge the legal parenthood of the intended parents. Furthermore, the child was separated from the intended parents, taken into custody and a guardian was appointed. First the child was placed in an orphanage and later in a foster family.

The European Court of Human Rights did not decide whether the child's rights under the Convention had been violated. It considered the complaint by the intended parents on behalf of the child inadmissible because the intended parents were not able to represent the child. ${ }^{21}$

The Court concluded however that the intended parents' right to respect for their family life under Article 8 of the Convention was violated. As they provided for the child for a period of at least half a year, there "existed a $d e$ facto family life" between the intended parents and the child protected by the Convention. ${ }^{22}$ The Italian State had not exceeded the limits of its discretion by refusing to recognize the intended parents' legal parenthood of the child..$^{23}$ Here it was free to take into account the fact that there was no genetic link between the intended parents and the child.

However, the Italian State should not have removed the child from the intended parents. According to the Court, the removal of the child violated the interests of the child which are ultimately decisive. ${ }^{24}$ Separating a child from its factual family must remain an exceptional measure for situations in which leaving the child in the family would expose the child to immediate danger. This applies irrespectively whether or not a genetic link between the members of the family exists.

\section{4}

This judgement also left many questions regarding the legal descent of children born due to surrogacy arrangements unanswered. However, although the Court did not decide whether the child's rights granted by the Convention had been violated, the judgement has far-reaching consequences for the child's legal descent.

If, according to the Court, it is necessary to leave the child permanently with its intended parents, it is hardly conceivable that a signatory of the Convention asserting its own legal position may permanently deny this protected factual family legal recognition. On the contrary, the child's right to respect for its private life under Article 8 of the Convention then requires to also establish the child's legal descent from the intended parents with whom the child permanently lives. ${ }^{25}$

A state that generally rejects surrogacy may accomplish this in different ways. It can recognize foreign judgments which provide for a legal descent from the intended parents as is the case in Germany. ${ }^{26}$ It may establish the legal descent by applying the law of the respective foreign country which, like Russia, provides for a regulation of surrogacy. ${ }^{27}$ And if the state only 
applies its own law that rejects surrogacy, it may allow the intended parents to adopt the child. ${ }^{28}$

In effect, the factual situation induced by a surrogacy arrangement is subsequently only legally recognized. The present legal guidelines defined by the European Court of Human Rights demand that even states like Germany that generally reject surrogacy eventually establish a legal parent-child-relationship between the intended parents and the child. ${ }^{29}$

\section{IV}

However, the Court's previous judgements in the cases of Mennesson and Labassee prohibit a strict implementation of the German rejection of surrogacy. If one is not willing to regularly and permanently adopt foreign approaches towards surrogacy, the only possibility is to allow surrogacy - at least to a limited degree also under German law. ${ }^{30}$ This is the only way to eliminate the necessity for intended parents to use the services of a surrogate mother under occasionally questionable circumstances abroad. How the regulation of surrogacy could be designed and in what way it might be restricted will largely depend on further indications by the European Court of Human Rights.

1 Sec. 1 para. 1 No. 7 of the Embryo Protection Act (Embryonenschutzgesetz, BGBl. 1990 I, 2746) and sec. 14b, 13c of the Adoption Placement Act (Adoptionsvermittlungsgesetz, BGB1. 2002 I, 354). (2013). An overview of the German legal situation concerning surrogacy can be found in Gössl, Germany, in: Trimmings/Beaumont (Eds.), International Surrogacy Arrangements, 131 et seq.; Mayer, RabelsZ 78 (2014), 551, 563 et seq.

Sec. 1591 of the German Civil Code.

3 Art. 51 No. 4 subs. 2 of the Family Code (Семейный кодекс Российской Федерации” от 29.12.1995 N 223-Ф3), Art. 16 No. 5 of the Federal Law on civil status (Федеральный закон от 15.11.1997 N 143-Ф3 (ред. от 03.07.2016) “Об актах гражданского состояния").

$4 \quad$ Art. 52 No. 3 subs. 2 of the Family Code (cf. Fn. 3).

5 Art. 51 No. 4 subs. 2 of the Family Code (cf. Fn. 3), Art. 16 No. 5 of the Federal Law on civil status (cf. Fn. 3).

6 Russian Constitutional Court, Decision No. 880-O of May 15, 2012 (Определение Конституционного Суда РФ от 15.05.2012 N 880-O).

7 For an overview see Dethloff, JZ 2014, 922, 923 et seq.; Helms, StAZ 2013, 114, 114 et seq.; Lederer, Grenzenloser Kinderwunsch, 2016, pp. 81 et seq.; Mayer, RabelsZ 78 (2014), 551, 555 et seq. Also the European Parliament's Committee on Legal Affairs requested A Comparative Study on the Regime of Surrogacy in EU Member states that can be downloaded from <http://www.europarl.europa.eu/RegData/etudes/etudes/join/2013/474403/IPOL-JURI_ET(2013)474403_EN.pdf>.

8 See BGH (10.12.2014), NJW 2015, 479, 480; Dutta, Künstliche Fortpflanzung in „Anbieterrechtsordnungen“ - ein Blick über Europa hinaus, in: Dutta/Schwab/Henrich/Gottwald/Löhnig (Eds.), Künstliche Fortpflanzung und europäisches Familienrecht, pp. 355, 363 et. seq.; Rauscher, JR 2016, 97, 99 et seq.

9 ECtHR [Fifth Section, 26.06.2014], Application No. 65192/11 (Mennesson/France); ECtHR [Fifth Section, 26.06.2014], Application No. 65941/11 (Labassee/France); for a comment on these decisions see Engel, StAZ 2014, 353 et seq.

10 ECtHR [Fifth Section, 26.06.2014], Application No. 65192/11 (Mennesson/France), § 79; ECtHR [Fifth Section, 26.06.2014], Application No. 65941/11 (Labassee/France), §58.

11 ECtHR [Fifth Section, 26.06.2014], Application No. 65192/11 (Mennesson/France), § 84; ECtHR [Fifth Section, 26.06.2014], Application No. 65941/11 (Labassee/France), § 63.

12 ECtHR [Fifth Section, 26.06.2014], Application No. 65941/11 (Labassee/France), § 37; ECtHR [Second Section, 27.01.2015], Application No. 25358/12 (Paradiso and Campanelli/Italy), § 67; Grabenwarter, European Convention on Human Right - Commentary, 2014, Art. 8 para. 19.

13 ECtHR [Fifth Section, 26.06.2014], Application No. 65192/11 (Mennesson/France), §§ 80, 96, 99; ECtHR [Fifth Section, 26.06.2014], Application No. 65941/11 (Labassee/France), $\S \S 38,59,75$.

14 ECtHR [Fifth Section, 26.06.2014], Application No. 65192/11 (Mennesson/France), §§ 92, 94, 102; ECtHR [Fifth Section, 26.06.2014], Application No. 65941/11 (Labassee/France), §§ 71, 73, 81.

15 ECtHR [Fifth Section, 26.06.2014], Application No. 65192/11 (Mennesson/France), §§ 96, 99, 101; ECtHR [Fifth Section, 26.06.2014], Application No. 65941/11 (Labassee/France), $\S \S 75,78,80$.

16 ECtHR [Fifth Section, 26.06.2014], Application No. 65192/11 (Mennesson/France), § 100; ECtHR [Fifth Section, 26.06.2014], Application No. 65941/11 (Labassee/France), § 79.

17 BGH (10.12.2014), NJW 2015, 479, 480 et seq.; for comments on this decision see Coester-Waltjen, Forum Familienrecht 2015, 186 et seq.; Heiderhoff, NJW 2015, 485; Henrich, IPRax 2015, 229 et seq.; Mayer, StAZ 2015, 33 et seq.; Schall, DNotZ 2015, 306 et seq.

18 BGH (10.12.2014), NJW 2015, 479, 481, 483.

19 The following remarks relate to the decision of the Court's Second Section of January 27, 2015 (ECtHR [Second Section, 27.01.2015], Application No. 25358/12 [Paradiso and Campanelli/Italy]); for comments on this decision see Duden, StAZ 
2015, 201 et. seq.; Henrich, FamRZ 2015, 561 et seq. On January 24, 2017 the Court's Grand Chamber delivered the final judgement in this case (ECtHR [Grand Chamber, 24.01.2017], Application No. 25358/12 [Paradiso and Campanelli/Italy]).

20 The ECtHR assumes that at the time of the child's birth in February 2011 there was no clear necessity for a genetic link between the intended parents and the child under Russian law (ECtHR [Second Section, 27.01.2015], Application No. 25358/12 (Paradiso and Campanelli/Italy), § 76; ECtHR [Grand Chamber, 24.01.2017], Application No. 25358/12 (Paradiso and Campanelli/Italy), § 73). Today Russian law requires that there is no biological link between the surrogate mother and the child and that the intended parents' gametes are used for the insemination (Art. 55 No. 10 of the Federal law on the basis of the protection of citizens' health [Федеральный закон от 21.11.2011 N 323-Ф3 (ред. от 03.07.2016) “Об оссновах охраны здоровя граждан в Российской Федерации"]; section 77 of the Decree No. 107 by the Russian Health Ministry [Приказ Минздрава России от 30.08.2012 N 107н (ред. от 11.06.2015) “О порядке использования вспомогательных репродуктивных технологий, противопоказаниях и ограничениях к их применению”).

21 ECtHR [Second Section, 27.01.2015], Application No. 25358/12 (Paradiso and Campanelli/Italy), §§ 49 et seq.; ECtHR [Grand Chamber, 24.01.2017], Application No. 25358/12 (Paradiso and Campanelli/Italy), § 84, 86.

22 ECtHR [Second Section, 27.01.2015], Application No. 25358/12 (Paradiso and Campanelli/Italy), § 69. The Court's Grand Chamber on the contrary decided that due to the missing genetic link between the intended parents and the child, the short duration of their cohabitation and "the uncertainty of the ties from a legal perspective" no family life was established (ECtHR [Grand Chamber, 24.01.2017], Application No. 25358/12 [Paradiso and Campanelli/Italy], §§ 157, 198, 208).

23 ECtHR [Second Section, 27.01.2015], Application No. 25358/12 (Paradiso and Campanelli/Italy), $\S 77$.

24 ECtHR [Second Section, 27.01.2015], Application No. 25358/12 (Paradiso and Campanelli/Italy), $\S \S 80$ et seq. According to the decision of the Court's Grand Chamber the removal of the child only (cf. Fn. 22) interfered with the intended parents' private life but was justified under Art. 8 para. 2 ECHR by the Italian public interest "to recognise a legal parent-child relationship [...] solely in the case of a biological tie or lawful adoption" (ECtHR [Grand Chamber, 24.01.2017], Application No. 25358/12 [Paradiso and Campanelli/Italy], $\S \S 163,177,188,197,204,209,215$ ).

25 With regard to the legal recognition of the protected factual family life see Duden, StAZ 2015, 201, 205; Henrich, FamRZ 2015, 561 et seq.; Henrich, IPRax 2015, 229, 233.

26 BGH (10.12.2014), NJW 2015, 479 et seq.; Benicke, StAZ 2013, 101, 103 et seq.; Dethloff, JZ 2014, 922,925 et seq.; Duden, Leihmutterschaft im Internationalen Privat- und Verfahrensrecht, 2015, pp. 111 et seq.; Duden, StAZ 2014, 164 et seq.; Mayer, RabelsZ 78 (2014), 551, 568 et seq.

27 Duden, Leihmutterschaft im Internationalen Privat- und Verfahrensrecht, 2015, pp. 29 et seq.; Benicke, StAZ 2013, 101, 106 et seq.; Dethloff, JZ 2014, 922, 929 et seq.; Siehr, StAZ 2015, 258, 267; Mayer, RabelsZ 78 (2014), 551,578 et seq.

28 Benicke, StAZ 2013, 101, 111 et seq.; Dethloff, JZ 2014, 922, 930 et seq.; Duden, Leihmutterschaft im Internationalen Privat- und Verfahrensrecht, 2015, pp. 23 et seq., 312 et seq., 323; Lederer, Grenzenloser Kinderwunsch, 2016, pp. 157 et seq.

29 On the basis of the judgement delivered by the Court's Grand Chamber stating that the removal of the child from the intended parents does not violate Art. 8 ECHR (ECtHR [Grand Chamber, 24.01.2017], Application No. 25358/12 [Paradiso and Campanelli/Italy], § 216) the signatories of the Convention remain entitled to refuse the legal acknowledgement of certain parent-child-relationships that are based on surrogacy arrangements.

30 With regard to the need for legislative changes see Witzleb, „Vater werden ist nicht schwer“?, in: Witzleb/Ellger/Mankowski/Merkt/Remien (Eds.), Festschrift für Dieter Martiny zum 70. Geburtstag, pp. 203, 239 et. seq.; Benicke, StAZ 2013, 101, 114 et seq.; Dethloff, JZ 2014, 922, 931 et seq.; Mayer, RabelsZ 78 (2014), 551, 588 et seq.; Duden, Leihmutterschaft im Internationalen Privat- und Verfahrensrecht, 2015, p. 332.

\title{
Транснациональное суррогатное материнство в свете судебной практики Европейского суда \\ по правам человека
}

\author{
Кристиан Калин \\ Университет Пассау, \\ Германия, 94032, Пассау, Иннштрассе, 41
}

Суррогатное материнство является особенно деликатной темой. В этой связи нормы суррогатного материнства в различных европейских правовых системах значительно расходятся. В соответствии с Европейским судом по правам человека каждая страна, подписавшая Европейскую конвенцию о правах человека, на свое усмотрение имеет право разрешить или запретить суррогатное материнство. Однако решение второй секиии суда в судебном разбирательстве Парадизо и Кампанелли требует, чтобы страны, подписавщие Конвенцию, которые 
обычно отвергают суррогатное материнство, устанавливали правовые отношения между предполагаемьми родителями и детьми, родивщимися за гранищей, в рамках отношений суррогатного материнства.

Ключевые слова: суррогатное материнство, происхождение, Европейская конвенция о правах человека, семейная жизнь, Европейский суд по правам человека, публичный порядок.

Научная специиальность: 12.00.00 - юридические науки. 